\begin{tabular}{|c|c|}
\hline \multirow{3}{*}{ 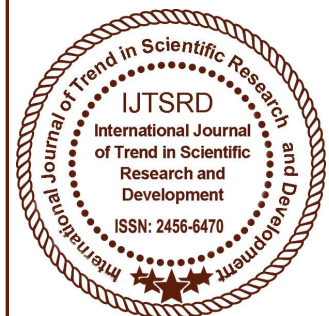 } & $\begin{array}{l}\text { International Journal of Trend in Scientific } \\
\text { Research and Development (IJTSRD) }\end{array}$ \\
\hline & International Open Access Journal \\
\hline & ISSN No: 2456 - 6470 | www.ijtsrd.com | Volume - 1 | Issue - 5 \\
\hline
\end{tabular}

\title{
A Study based on Legalized Scenario for Safety and Protection of Environment
}

\author{
Lav Mohan \\ Research Scholar, Management Department, \\ Monad University, Hapur, Uttar Pradesh, India
}

\author{
Deepanshu Agarawal \\ Associate Professor, Monad University \\ Hapur, Uttar Pradesh, India
}

\section{ABSTRACT}

The familiarity with hazard postured to the general public and environment from operation of real businesses, for example, the compost fabricating, have brought about various activities went for keeping up and constantly enhancing security and environment culture in the business. Contamination counteractive action through implementation of the stipulations of the different control legislations and related principles and directions is an essential piece of Environmental Management. The essential premises of such legislation are anticipation of real mishap perils and constraining the outcomes of such mischances for humanity as well as for the environment. It put more accentuation on the socio specialized parts of control approach and endeavor to bring more straightforwardness and receptiveness into the procedure by taking into account open conference and by reinforcing the part of statutory experts through data trade . In this part, the different authorizations of the Government of India on the environmental front that have an immediate bearing on the operation of compost plants are inspected.

Keywords: Environment, management, protection, legal etc

\section{INTRODUCTION:}

Environmental protection is a routine with regards to ensuring the common habitat on singular, association controlled on legislative levels, for the advantage of both the earth and people. Because of the weights of overconsumption, populace and innovation, the biophysical condition is being corrupted, here and there for all time. This has been perceived, and pranith have started setting restrictions on exercises that reason environmental debasement. Since the 1960s, action of environmental developments has made familiarity with the different environmental issues. There is no concurrence on the degree of the environmental effect of human action and even logical deceptive nature happens, so protection measures are once in a while wrangled about.

Development of the fertiliser industry is very important to improve agricultural productivity and enhance food production to feed the increasing population. Growth of fertiliser industry, however, causes serious environmental problems. Environmental considerations, therefore, assume importance in respect of fertiliser and several other industries. The process involved in the production of fertilisers generates effluents and the emissions contribute to environmental degradation such as green house effect, stratospheric ozone depletion, acid rain and acidification, eutrophication, soil degradation, technological hazards, chemical mists etc. With potential damage to human race. Thus, on the one hand we have the dire necessity to increase fertiliser production for maintaining food security while on the other hand the consequential environmental issues are to be tackled effectively to avoid damages. Environmental management assumes paramount importance in this perspective to address the 
numerous issues relating to pollution control, safety etc., and to minimize the degradation of the environment on account of developmental activities.

\section{Constitutional Provisions for environment protection:}

The Directive Principles of State Policy in the Constitution of India accommodate the Safety and change of environment and defending of backwoods and natural life. The State should attempt to ensure and enhance the environment and to shield the woods and natural life of the nation. The Constitution additionally announce that it should be the obligation of each national in the nation to ensure and enhance the regular habitat including backwoods, lakes, waterways and natural life, and to have sympathy for living animals. The dialect of the Directive Principles of State Policy (Article 47) requires a safetyist position by the state as well as constrains the state to look for the change of contaminated environments. This enables the legislature to force limitations on conceivably destructive substances, for example, contaminating enterprises. India was among the primary gathering of nations to embed an alteration into its Constitution enabling the State to ensure and enhance the environment for shielding general wellbeing, woodlands and natural life. The 42nd Amendment of the Constitution of India, revering the significance of environmental wellbeing was embraced in 1976 and came to impact January 3,
1977. The Indian Penal Code, go in 1860, punishes person(s) in charge of causing contamination of water of an open spring or repository with detainment or fines (Shamad D, 1996). The Indian Forest Act was a result of British control in 1927. It mirrored the British strategy of misuse of common assets as opposed to the want to safeguard and secure the woods environment. It gave huge rights on Governments to misuse the backwoods assets. The British viewed the woods as a wellspring of supply of timber for assembling railroad sleepers. Indeed, even at this beginning time, familiarity with man's dangerous inclinations was rising. The Factory Act likewise tended to open security and medical problems. Area 12 of the Act enabled each state government to administer its own guidelines and all through the 1950's and 1960's individual states confined their own principles under the Act. The legislation has without a doubt tended to the inquiry concerning the release of water and effluents by production lines and called for successful courses of action for transfer at the plant level. Rebelliousness of these arrangements is subject to welcome disciplines. Despite the fact that we have various legislation encouraging environmental security the fundamental issue still stay as aimless misuse of nature and negligent presentation of high innovation overlooking the requirement for environmental wellbeing. (Diwan P. also, Diwan P, 1998).

\section{Environment Protection Act}

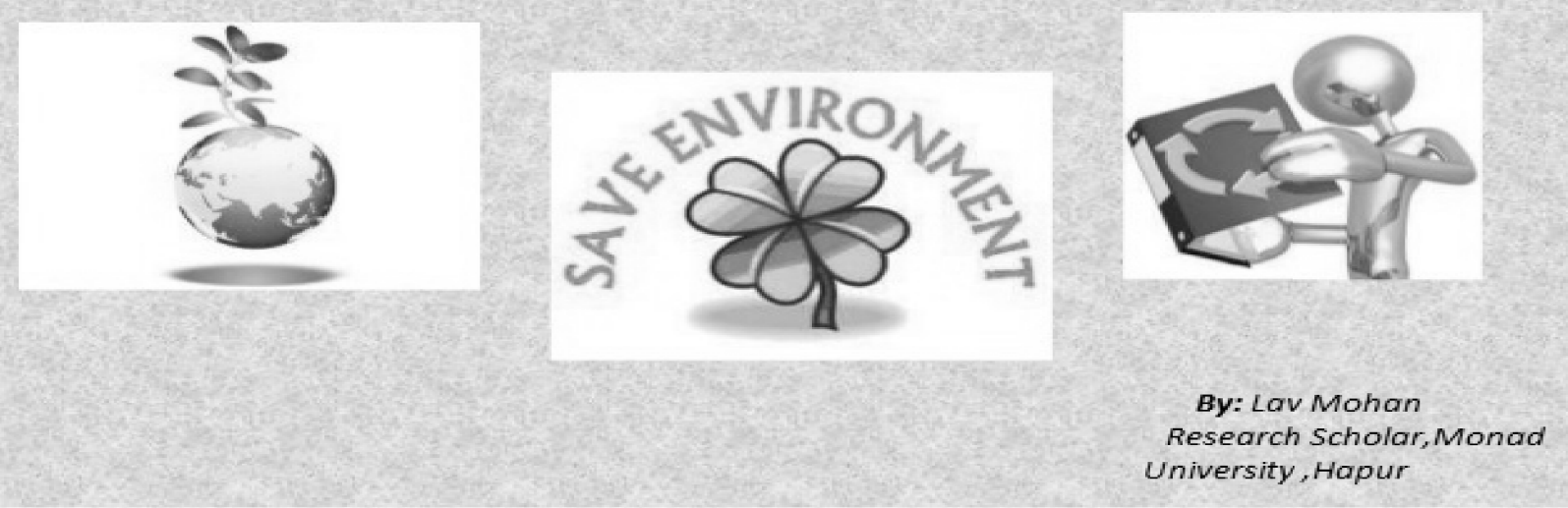

(Fig.1 Environment Protection) 


\subsection{The Water (Prevention and Control of Pollution) Act, 1974:}

The Water (Prevention and Control of Pollution) Act was passed in 1974. Production of an administrative organization for controlling water contamination denoted the start of various environmental legislations by the Indian Parliament. The Water Act additionally settled the Central Pollution Control Board (CPCB) at focal government level and State Pollution Control Board (SPCB) at the state government levels. A portion of the primary duties of the Central Board in advancing contamination reduction included organizing exercises of state sheets and settling question among them; giving specialized help; leading examinations; opening labs for investigation of tests; building up expenses for various sorts of test testing; looking into issues and issues; preparing faculty; directing media and open mindfulness crusades; gathering and dispersing information on water contamination; and working with state sheets to set measures. The state sheets under take plant-level examinations and observing, and instructing the Central Board with respect to issues and patterns at the nearby level. Plants can be required to give the state data on their contamination control advances. The Central Pollution Control Board (CPCB) has established the Minimal National Standards (MINAS) for significant industry parts including manures. An instrument of 'Assent' is utilized by the PCBs for control of contamination through legitimate arrangements. Manure units are required to get an assent, which is conceded in the wake of confirming that the conditions stipulated are completely followed. The assent manages the quality and amount of effiuents that can be released over some stretch of time. Consequent alterations to the Act were made to beat troubles in usage of standards, siting of businesses, enable the Board to arrange direction or conclusion of exorbitantly contaminating units and offer appropriate to subjects to start lawful activity against dirtying industry. The Water (Prevention and Control of Pollution) Cess Act declared in 1977 furnished the Central and state sheets with the specialist to exact and gather a duty on ventures utilizing water (F AI, 2000).

2.2 Air (prevention and Control of Pollution) Act, 1981:

The Air (Prevention and Control of Pollution) Act was passed in 1981 for the avoidance, and control of air contamination and safeguarding of air quality. Under the arrangements of this Act, the CPCB is approved to create national norms for nature of air and devise intends to forestall, control and decrease contamination. The State Pollution Control Board will exhort the State Government with respect to the appropriateness of area for setting up any industry that is probably going to cause contamination. Clamor is additionally incorporated into the rundown of air toxins and arrangements of the Act are made material for its control.

\subsection{Environment (security) Act, 1986 :}

In 1986, the Parliament passed the Environment (Safety) Act, intended to go about as umbrella legislation on the environment. The duty endowed to oversee the new legislation likewise tumbled to the focal and state contamination control sheets. In 1993. the Ministry of Environment and Forests (MoEF) of the Government of India finished its Environmental Action Plan to coordinate environmental contemplations into formative techniques, which, among different needs, included modern contamination lessening. The Ministry likewise chose to move from focus to stack based guidelines, This would add to a polluter'S expenses and evacuate motivating forces to weaken effluents by including water, and reinforce motivators for reception of cleaner innovations. It likewise issued water utilization principles for various enterprises and proposed extra punishment for extreme water utilize. Focusing on little scale businesses has been a critical undertaking also since these offices significantly add to the contamination stack. The Ministry gives specialized help and constrained awards to advance focal gushing treatment plants. It has likewise made mechanical zones to empower groups of comparative enterprises keeping in mind the end goal to help diminish the cost of giving utilities and environmental administrations. Under this measure, the Central Government has obligation regarding choosing models, confining mechanical destinations, setting down techniques and protections for mischance avoidance and treatment of perilous waste, managing of examinations and research on contamination issues, nearby assessments, foundation of labs, and accumulation and scattering of data. The bill likewise sets guidelines on particular poisons in particular mechanical areas including manure ventures. The measure gives rules to area of enterprises and mining zones, for allowing 'and confining businesses in 
environmentally touchy territories, beach front zone directions and environmental effect evaluations of improvement ventures. Councils met to direct Environment Impact Assessments must have teachers in eco-framework and water asset administration, air and water contamination control, greenery preservation. arrive utilize arranging, sociologies, nature and environmental wellbeing. Open hearings are additionally pre-essential for venture freedom. The law additionally proclaims controls on unsafe waste administration and taking care of. The demonstration characterizes the duties of handlers, conditions for giving approval, states of transfer destinations, rules for bringing in dangerous squanders, announcing of mishaps, bundling and naming prerequisites and an interest procedure for potential handlers who have been denied approval. Standards were additionally declared on the make, stockpiling and import of perilous or poisonous chemicals, miniaturized scale living beings, hereditarily designed life forms, or cells. Out of the blue, private residents were given the privilege to document bodies of evidence against noncomplying plants.

\subsection{Hazardous Wastes (Management and Handling) Rules, 1989 :}

The motivation behind these tenets is to direct the treatment of risky substances and build up a control system for the administration of perilous squanders. Under the principles it might be the obligation of the office administrator to appropriately gather get, treat, store and arrange these materials securely at areas expected for the same under the expert conceded to them by the State Pollution Control Boards. A portion of the risky squanders related with compost industry as controlled above are materials containing chromium, arsenic, ooze from water treatment plants, corrosive, soluble base and slurry squanders, spent impetuses and so forth.

\subsection{Produce, Storage and Import of Hazardous Chemical Rules, 1989:}

These tenets endorse systems and shields for the anticipation of mishaps emerging out of the utilization of dangerous and poisonous chemicals in ventures. The rundown of such chemicals incorporate smelling salts, arsenic trioxide, hydrogen, oxides of nitrogen, sulfur, vanadium and its mixes, chromium and its mixes and so on., that are widely utilized as a part of the manure business. It has been made the obligation of the occupier of the office to distinguish significant dangers and make satisfactory preventive strides, give data, preparing and hardware to the staff at work to guarantee their security, give data to all who are probably going to be influenced by a noteworthy mischance, create material wellbeing information sheets for such chemicals and get ready security reports and on location crisis designs. Resulting to the corrections in 1994, it has turned out to be compulsory for plants to do wellbeing reviews each year and present the answer to the specialists. Ridicule drills were additionally made compulsory.

\subsection{Commotion Pollution (Regulation and Control) Rules, 2000 :}

Though the expanding surrounding clamor levels in broad daylight places from different sources, including mechanical movement effectsly affect human wellbeing and the mental prosperity of the general population, it is viewed as important to direct and control commotion delivering and creating sources with the target of keeping up the encompassing air quality guidelines in regard of clamor. The State Government may sort the zones into mechanical, business, private or quiet regions/zones and indicate surrounding air quality gauges in regard of clamor for various areaslzones with the end goal of usage of commotion guidelines for various regions. The State Government should take measures for reduction of commotion and guarantee that the current clamor levels don't surpass the encompassing air quality principles determined under these guidelines. All advancement experts, neighborhood bodies and other concerned specialists should think about all parts of clamor contamination as a parameter of personal satisfaction to stay away from commotion danger and to accomplish the target of keeping up the encompassing air quality models in regard of commotion.

\subsection{The Public Liability Insurance Act, 1991 :}

The Act is expected to give quick alleviation to people influenced by mischances while taking care of risky materials. The proprietor is made at risk to give help for damage or demise of any individual or harm to any property coming about because of a mischance. It is likewise required for the proprietor to have protection cover for such potential obligation. An Environmental Relief Fund was built up and is kept up by industry administrators. The Government authorized the National Environmental Tribunal Act, 
1995 to accommodate strict risk for harms emerging out of mishaps from treatment of dangerous substances. The council guarantees rapid alleviation and remuneration to the influenced.

\section{Conclusions:}

The unpredictability of the procedure advancements being received in manure plants makes it troublesome, if certainly feasible, for anyone other than the proprietor and administrator to do point by point review on the frameworks, practices and control approach so frequently in charge of the avoidance of environmental harms. Subsequently, satisfactory directions, which could be upheld on office proprietors and administrators through the specialist of the Government and neighbourhood organization, are important to deal with open security and environmental wellbeing. The prerequisites of such controls additionally should be refreshed as one with the advancements in innovation of the procedure utilized for generation.

\section{REFERENCES}

1) Duffield. J.S. The Impact of Legislation and Industry Initiatives: Strategies for

2) Industrial Risk Prevention and Management in the European Union: Proceedings of

3) the 1 (/h International Symposium on Loss Prevention and Safety Promotion in the

4) Process Industries, European Federation of Chemical Engineering, Stockholm,

5) Sweden, 2001, pp.1223-1228.

6) Shaman. David, India's Pollution Regulatory Structure and Background, NIPRNew Ideas in Pollution Regulation, The World Bank Group, Jan., 1996, p.2.

7) Diwan, Paras Dr. and Diwan, Parag Dr., Ed., Environmental Management Law and

8) Administration, Vanity Books International, New Delhi, 1998.

9) F Al Website, Fertiliser Association of India, New Delhi, 2000. 